\title{
Who Should Use a Face Mask During COVID-19 Pandemic? An Evidence-Based Review
}

\author{
Suresh K. Sharma, Ravi Kant ${ }^{1}$ \\ Dean (Nursing), 'Director, All India Institute of Medical Sciences, Rishikesh, Uttarakhand, India
}

\section{Abstract}

There is a lot of confusion about who should use face mask during this serious COVID-19 pandemic. Irrational use of masks has caused serious shortage of mask availability for frontline health-care workers, who really require it. Therefore, the authors have carried out this comprehensive evidence-based review to guide policy-makers for the rational use of the face mask in this crisis. Social distancing, meticulous hand hygiene and respiratory etiquettes are more important in curbing the COVID-19 infection transmission rather than use of face mask alone but people may use multilayer cloth face covering especially in the areas of significant community-based transmission of SARS-CoV-2. Frontline health-care workers essentially require the full set of personal protective equipment, including gown, gloves, goggles or face shields, shoe covers, and mask, preferably N95 or equivalent respirator when exposed to aerosols. In case, N95 or equivalent equipment is not available, and then, surgical mask can also protect them adequately during non-aerosol generating procedures, provided meticulous hand hygiene is practiced.

Keywords: COVID-19, COVID-19 pandemic, face mask, mask, N95 mask, SARS-CoV-2

\section{INTRODUCTION}

The universal use of face mask in the hospitals is a standard practice in some parts of the world such as Singapore, Hong Kong, and other Asian countries, which was also recently adapted by some of the hospitals in other parts of the world. The use of mask is a routine practice when health-care workers are involved in care of patients with viral respiratory infections, but otherwise, it is not considered as the essential component of barrier precaution. Frontline health-care workers involved in care of suspected or confirmed COVID-19 patients essentially require the use of mask, preferably N95 mask when exposed to aerosolized droplets. ${ }^{[1]}$ However, the big question is that "Is universal use of face mask by all health-care workers during COVID-19 pandemic essential?."

Does wearing face mask outside health-care facilities offer any potential benefits and is it really required? Epidemiologist defines the risk of infection only if individual is exposed face-to-face with an infected person within 6 feet for more than 10-30 min. In this case, there is very little chance of an individual contracting SARS-CoV-2 infection with casual interactions with people in public space. ${ }^{[2]}$ However, the use of face mask outside health-care settings in public

\begin{tabular}{|l|l|}
\hline \multicolumn{2}{|c|}{ Access this article online } \\
\hline Quick Response Code: & Website: \\
\hline & www.ijrconline.org \\
\cline { 2 - 2 } & \\
\hline
\end{tabular}

places has also been observed, may be because of conflicting reports and fear of catching infection during this rapidly spreading pandemic. Recently, the media reported that some countries, including the USA, the UK, Spain, Italy, and India, are experiencing acute shortage of protective equipment, especially face masks for health-care workers.$^{[3]}$ Irrational use of face mask by general public and health-care workers has caused acute shortage of masks, ${ }^{[4]}$ and they are not available for the frontline health-care workers when they really require it. Thus, a need was felt to carry out an extensive review to guide policy-makers by empirically answering the question as to who really requires to wear a face mask during COVID-19 pandemic. This review presents evidence on possible mode of transmission of SARS-CoV-2 and evidence-based recommendations about the rational use of face mask during COVID-19 pandemic.

Address for correspondence: Prof. Suresh K. Sharma, College of Nursing, All India Institute of Medical Sciences, Rishikesh, Uttarakhand, India. E-mail: skaiims17@gmail.com

This is an open access journal, and articles are distributed under the terms of the Creative Commons Attribution-NonCommercial-ShareAlike 4.0 License, which allows others to remix, tweak, and build upon the work non-commercially, as long as appropriate credit is given and the new creations are licensed under the identical terms.

For reprints contact: reprints@medknow.com

How to cite this article: Sharma SK, Kant R. Who should use a face mask during COVID-19 pandemic? An evidence-based review. Indian J Respir Care 2020;9:149-52.

Received: $03-04-2020$ Accepted: $18-04-2020$

Revised: 07-04-2020 Published: 05-06-2020 


\section{Methods}

\section{Search strategy}

Review authors searched MEDLINE (Ovid, 2005-2020), Embase (Ovid, 2005-2020), and clinical trial registers (last search April 2, 2020). We used free-text terms and MeSH terms such as mask, face mask, N95 mask and prevention of viral infection transmission, and use of mask and viral pandemic for searching studies. We explored all articles related to present review and also used a list of references from searched published studies to identify new relevant studies.

\section{Data extraction}

Data regarding the modes of transmission of SARS-CoV-2, guidelines for personal protective equipment (PPE) use for COVID-19 pandemic, randomized controlled trials on the efficacy of mask, and face mask or N95 mask in the prevention of viral infection transmission were extracted. Finally, 31 articles were found suitable to be considered for writing this comprehensive evidence-based review.

\section{Mode of Transmission OF SARS - CoV-2}

This viral disease has been found to be transmitted primarily by aerosolized droplets generated during coughing, sneezing, or breathing, and direct and indirect contact transmissions..$^{[5-10]}$ In an analysis of 75,465 COVID-19 cases in China, air-borne transmission was not reported. ${ }^{[1]}$ An experimental study published recently in New England Journal of Medicine analyzed the sustainability of SARS-CoV-2 outside the human body and found that the virus was detectable for as long as 3 $\mathrm{h}$ in aerosolized droplets, raising the concern about possible air-borne transmission of this virus. ${ }^{[12]}$ However, the World Health Organization (WHO) report presents an argument that high-powered machine used for generating aerosol in this experiment does not reflect normal human cough conditions, and thus, the presence of COVID-19 virus in aerosol particles up to $3 \mathrm{~h}$ may not reflect a real-life clinical scenario. ${ }^{[13]}$ Contrarily, another study conducted in a real clinical scenario, reported presence of SARS-CoV-2-laden aerosols in air up to 4 meters from the patient, where ICUs were more contaminated compared to general wards ( $66.7 \%$ vs $8.3 \%$ ). These findings deepen the doubt about risk of airborne transmission in the health care settings in particular. ${ }^{[14]}$ Feco-oral transmission has also been suspected as the virus that was isolated from the feces of some patients ${ }^{[15]}$ but there is no confirmed report yet of feco-oral transmission of this virus [Table 1].

In addition, a study conducted in the real clinical scenario at the Washington University, St. Louis, Missouri, USA, analyzed the aerosols generated during extubation, bronchoscopy, suctioning, invasive mechanical ventilation, noninvasive ventilation, and nebulized medication administration. They found that significant small aerosol particles were generated only with the administration of nebulized medication, and no viruses, including any of influenza, were recovered in aerosolized droplets except few viable bacteria such as

\section{Table 1: Mode of transmission of SARS-CoV-2}

Aerosolized droplets generated through coughing, sneezing or breathing ${ }^{[5-10]}$

Direct contact with patient and its body fluids including faeces ${ }^{[5-10]}$ Indirect contact with surfaces and fomites (virus can survive on surfaces for longer period: plastic/ stainless steel: 2-3 days; cardboard: $24 \mathrm{hrs}$ and copper: 4 hours) ${ }^{[12]}$

Airborne transmission is suspected but not yet confirmed? ${ }^{[11]}$ (virus can survive in droplet particle in air up-to 3-hours ${ }^{[12]}$ and was found upto 4-meter distance from patient ${ }^{[14]}$ )

Faecal-oral route of transmission is also suspected? (SARS-CoV-2 is detected in faeces ${ }^{[15]}$ but no reports of faecal-oral transmission till date.)

Micrococcus luteus, Staphylococcus pasturei, and Bacillus flexus in five samples. This could be because of environmental or skin contaminants. ${ }^{[16]}$ These findings were further supported by a recent case study conducted at the Changi General Hospital, Singapore, where in spite of exposure to aerosol-generating procedures of a COVID-19 patient in an ICU, none of the health-care workers developed infection. ${ }^{[17]}$ Thus, it is clearly evident from available evidence that SARS-CoV-2 is transmitted only by droplet and contact transmission but risk of airborne transmission remains questionable and requires more empirical data for confirmation.

\section{Evidence about the Efficacy of Face Mask in Viral Infection Prevention}

The Center for the Disease Control and Prevention (CDC $)^{[1]}$ and $\mathrm{WHO},{ }^{[18]}$ both recommend the use of PPE - medical mask, gloves, gown, and eye protection (goggles or face shield), shoe covers by frontline health-care workers involved in care of COVID-19 patients. Recently, CDC revised its guidelines and now recommends optimized and extended used of face mask during the pandemic. ${ }^{[19]} \mathrm{CDC}$ as well as the WHO both mention that in case of nonavailability of N95 mask, surgical face mask may be used by health-care workers even when they are caring for SARS-CoV-2-infected patients.

A large randomized controlled trial on 2862 participants has also found that N95 masks were not superior to surgical masks for preventing influenza infection in health-care workers. ${ }^{[20]}$ These findings were further supported by a recent case study conducted at the Changi General Hospital, Singapore, where 41 health-care workers exposed to aerosol-generating procedures (endotracheal intubation, extubation, noninvasive ventilation, and exposure to aerosols in an open circuit) of a COVID-19 patient in an ICU, majority of them (85\%) had used only surgical face mask during this exposure. Surprisingly, none of them developed infection and were not found to be positive for COVID-19 on long-term follow-up and testing. ${ }^{[16]}$ This suggests that surgical masks, hand hygiene, and other standard procedures protected them from being infected. However, most of available guidelines recommend the use of N95 mask or equivalent equipment by health-care workers when performing aerosol-generating procedure for a COVID-19 patient. 


\begin{tabular}{|c|c|c|c|c|c|}
\hline \multirow[t]{2}{*}{ Type of face masks } & \multirow[t]{2}{*}{ Public } & \multirow[t]{2}{*}{ COVID-19 patient } & \multicolumn{2}{|c|}{ Caring for suspected/ confirmed COVID-19 patient } & \multirow[t]{2}{*}{ Non-COVID-19 patients } \\
\hline & & & $\begin{array}{c}\text { Family member } \\
\text { [informal caregiver] }\end{array}$ & Health Care Workers & \\
\hline Surgical face mask & $\mathrm{X}$ & $\sqrt{ }$ & $\sqrt{ }$ & $\sqrt{\#}$ & $\sqrt{ }$ \\
\hline N95 mask & $\mathrm{X}$ & $\mathrm{X}$ & $\mathrm{X}$ & $\sqrt{s}$ & $\sqrt{ } @$ \\
\hline $\begin{array}{l}\text { Multilayer cloth face mask } \\
\text { [Reusable] }\end{array}$ & $\sqrt{ } *$ & $\mathrm{X}$ & $\mathrm{X}$ & $\mathrm{X}$ & $\mathrm{X}$ \\
\hline
\end{tabular}

In a randomized controlled trial, 286 family members of confirmed cases of viral respiratory illness, including influenza and coronavirus, were randomized in three groups (surgical mask-94, P2 mask-90, and control group-102) and reported no significant difference in the relative risk of developing respiratory illness in the mask group and control group. ${ }^{[21]}$ Similarly, US CDC does not recommend the use of surgical face mask by general public. ${ }^{[22]}$ Even the WHO recommends that "people should not wear face mask unless they are sick with COVID-19 or are caring for someone who is sick with flu-like symptoms."[23] Considering available evidence about the modes of SARS-CoV-2 infection transmission, epidemiologists also assume that wearing masks outside health-care facilities has limited benefit. This is because the risk of infection is present only if the individual is exposed face-to-face with an infected person within 6-feet for more than 10-30 min. Casual passing through social space has very limited chances of contracting infection. ${ }^{[2]}$

A recent paper published by authors from Harvard Medical School ${ }^{[2]}$ explicitly mentioned use of mask alone reduces risk of infection transmission minimally, because it does not provide protection from droplets that may enter the eyes or transmission from fomites through hands to nasal, oral or ocular mucosa as person wearing mask may have increased tendency to touch their face. Furthermore, authors concluded that in light of worldwide mask shortage, social distancing, meticulous hand hygiene and other infection control measures are more valuable than use of face mask alone. Wearing mask may rather give a false sense of security in absence of meticulous hand hygiene, eye protection, gloves, and gown.

People argue that universal use of face mask may be helpful in protecting from contracting viral infection as an asymptomatic person may unknowingly spread the infection. This argument is supported by recently published scientific reports ${ }^{[24-28]}$, where it was found that a significant portion of asymptomatic and pre-symptomatic individuals can transmit the infection before developing symptoms of COVID-19. Consequently, on $4^{\text {th }}$ April, 2020 US CDC ${ }^{[29]}$ recommended use of cloth face covering, especially in the areas of significant community based transmission; however, cautions that general public should not use surgical face mask or N95 respirator mask and highlights that they should be reserved for healthcare workers as recommended by current US CDC guidelines. ${ }^{[22]}$ Furthermore, a study published in Nature Medicine ${ }^{[30]}$ on $3^{\text {rd }}$ April, 2020 identified surgical face masks significantly reduced detection of coronavirus RNA in aerosols, with a trend toward reduced detection of coronavirus RNA in respiratory droplets of symptomatic individuals. However, latest WHO advice on use mask in context of COVID-19 issued on 6th April, 2020 highlights that mask alone is insufficient to provide an adequate level of protection, and other measures such as hand hygiene, social distancing, coughing and sneezing etiquettes are more important. ${ }^{[31]}$

Therefore, based on available research evidences, the authors suggest that the general public must practice social distancing, meticulous hand hygiene, respiratory etiquettes rather than mere use of surgical face-mask. However, they may use multilayer cloth face mask especially in the areas of significant community based-transmission of SARS-CoV-2 to prevent the risk of asymptomatic and pre-symptomatic individuals spreading infection but it should not be used as substitute for social distancing (intrapersonal distance $>6$-feet). Symptomatic COVID-19 patients may use face mask to reduce the chances of disease spread to HCWs and others. Furthermore, frontline health care workers must use N95 mask when they have a risk of exposure to aerosols of a suspected or confirmed case of COVID-19 [Table-2].

\section{CONCLUSION}

SARS-CoV-2 is primarily transmitted through droplets and fomites, while there are remote possibilities of airborne or feco-oral routes of transmission. Therefore, social distancing, meticulous hand hygiene and respiratory etiquettes have significant role in curbing the infection transmission rather than use of face mask alone. However, people may use multilayer cloth face covering especially in the areas of significant community based transmission but it should not be used as substitute for social distancing. Use of surgical face mask by symptomatic COVID-19 may help in reducing the chances of disease spread to HCWs and others. Frontline health care workers caring for confirmed or suspected case of COVID-19 must use N95 mask at least when they have a risk of exposure to aerosols. 


\section{Financial support and sponsorship}

Nil.

\section{Conflicts of interest}

There are no conflicts of interest.

\section{RefERENCES}

1. Jeno M. CDC updates Guidelines on PPE for Health care Personnel. COVID-19 Declared a Pandemic; 11 March, 2020. Available from: https://www.aappublications.org/news/2020/03/11/coronavirus031120. [Last accessed on 2020 Apr 03].

2. Klompas M, Morris CA, Sinclair J, Pearson M, Shenoy ES. Universal masking in hospitals in the covid-19 era. N Engl J Med 2020. 3]. doi: 10.1056/NEJMp2006372.

3. Togoh I. Here's How Some of the Countries Worst hit by Coronavirus are Dealing with Shortages of Protective Equipment for Healthcare Workers; 31, Mar, 2020. Available from: https://www. for bes.com/sites/isabe ltogoh/2020/03/31/heres-ho w-some-of-thecountries-worst-hit-by-corona virus-are-dealing-with-short ages-ofprotective-equipment-for-health care-work ers/\#4111e4b52c13. [Last accessed on 2020 Apr 03].

4. Feng E, Cheng A. COVID-19 has Caused Shortage of Face Masks; but they are Surprisingly Hard to Make, 16, March, 2020. Available from: https://www.npr.org/sections/goats andsoda/2020/03/16/814929294/ cov id-19-has-caused-a-short age-of-face-masks-but-theyre-surpris ingly-hard-to-mak. [Last accessed on 2020 Apr 03].

5. Liu J, Liao X, Qian S, Yuan J, Wang F, Liu Y, et al. Community transmission of severe acute respiratory syndrome coronavirus 2, Shenzhen, China, 2020. Emerg Infect Dis 2020;26. doi.org/10.3201/ eid2606.200239.

6. Chan JF, Yuan S, Kok KH, To KK, Chu H, Yang J, et al. A familial cluster of pneumonia associated with the 2019 novel coronavirus indicating person-to-person transmission: A study of a family cluster. Lancet 2020;395:514-23.

7. Li Q, Guan X, Wu P, Wang X, Zhou L, Tong Y, et al. Early transmission dynamics in Wuhan, China, of novel coronavirus-infected pneumonia. N Engl J Med 2020;382:1199-207.

8. Huang C, Wang Y, Li X, Ren L, Zhao J, Hu Y, et al. Clinical features of patients infected with 2019 novel coronavirus in Wuhan, China. Lancet 2020;395:497-506. Available from: https://doi.org/10.1016/ S01406736(20)30183-5. [Last accessed on 2020 Apr 03].

9. Burke RM, Midgley CM, Dratch A, Fenstersheib M, Haupt T, Holshue M, et al. Active monitoring of persons exposed to patients with confirmed COVID-19-United States, January-February 2020. MMWR Morb Mortal Wkly Rep 2020;69:245-6.

10. World Health Organization. Report of the WHO-China Joint Mission on Coronavirus Disease 2019 (COVID-19) 16-24 February 2020. Geneva: World Health Organization; 2020. Available from: https:// www.who.int/docs/de fault- source/corona viruse/whochina-joint-mis sion-on-covid-19-fi nal-report.pdf. [Last accessed on 2020 Apr 03]

11. Ong SWX, Tan YK, Chia PY, Lee TH, Ng OT, Wong MS, et al. Air, surface environmental, and personal protective equipment contamination by severe acute respiratory syndrome coronavirus 2 (SARS-CoV-2) From a Symptomatic Patient. JAMA 2020;323:1610-2.

12. van Doremalen N, Bushmaker T, Morris DH, Holbrook MG, Gamble A, Williamson BN, et al. Aerosol and Surface Stability of SARS-CoV-2 as Compared with SARS-CoV-1. N Engl J Med 2020. doi: 10.1056/ NEJMc2004973.

13. World Health Organization. Mode of Transmission of Virus Causing COVID-19: Implications for IPC Permutation Recommondations. Scientific Brief. 29 March, 2020. Available from: http:// WHO/2019-nCoV/Sci_Brief/Trans mission_modes/2020.2. [Updated 2020 Mar 29; Last accessed on 2020 Apr 03].

14. Guo Z-D, Wang Z-Y, Zhang S-F, Li X, Li L, Li C, et al. Aerosol and surface distribution of severe acute respiratory syndrome coronavirus 2 in hospital wards, Wuhan, China, 2020. Emerg Infect Dis 2020;84:44-8

15. Wu D, Wu T, Liu Q, Yang Z. The SARS-CoV-2 outbreak: What we know. Int J Infect Dis 2020. S1201971220301235. doi: 10.1016/j. ijid.2020.03.004. [Epub ahead of print].

16. Li J, Leavey A, Yang W, O’Neil C, Wallance M, Boon A, et al. Defining aerosol generating procedures and pathogen transmission risks in healthcare settings. Open Forum Infect Dis 2017;4:S34-5.

17. $\mathrm{Ng} \mathrm{K}$, Poon BH, Kiat Puar TH, Shan Quah JL, Loh WJ, Wong YJ, et al. COVID-19 and the risk to health care workers: A case report. Ann Intern Med 2020;16:L20-0175. doi:10.7326/L20-0175.

18. World Health Organisation. Infection Prevention and Control Guidelines for Long Term care Facilities in the Context of COVID-19. Interim Guidelines; 21 March, 2020. Available from: http://WHO/2019-nCoV/ IP C_long_term_care/2020.1. [Updated 2020 Mar 29; Last accessed on 2020 Apr 03].

19. Centers for Disease Control and Prevention. Strategies for Optimizing the Supply of Facemasks; 17 March, 2020. Available from: https://www. cdc.gov/corona virus/2019-ncov/hcp/ppe-stra tegy/face-masks.html. [Updated 2020 Mar 29; Last accessed on 2020 Apr 03].

20. Radonovich LJ Jr., Simberkoff MS, Bessesen MT, Brown AC, Cummings DA, Gaydos CA, et al. N95 Respirators vs Medical Masks for Preventing Influenza Among Health Care Personnel: A Randomized Clinical Trial. JAMA 2019;322:824-33.

21. Maclntyre CR, Dwyer D, Seal H, Fasher M, Booy R, Cheung P, et al. The first randomized controlled trials of mask use in household to prevent respiratory viruses transmission. Int J Infec Dis 2008;12:E328.

22. Centers for Disease Control and Prevention. Coronavirus Disease 2019 (COVID-19). Available from: https://www.cdc.gov/corona virus/2019-ncov/hcp/health care-supply-ppe-index.html. [Updated 2020 Mar 29; Last accessed on 2020 Apr 03].

23. Howard J. WHO Stands by Recommendation to not Wear masks if you are not Sick or not Caring for Someone who is Sick. CNN World; 31 March, 2020. Available from: https://edition.cnn.com/2020/03/30/ world/corona virus-who-masks-recommen dation-trnd/index.html. [Last accessed on 2020 Apr 03].

24. Rothe C, Schunk M, Sothmann P, Bretzel G, Froeschl G, Wallrauch C, et al. Transmission of 2019-nCoV infection from an asymptomatic contact in germany. N Engl J Med 2020;382:970-1.

25. Bai Y, Yao L, Wei T, Tian F, Jin DY, Chen L, et al. Presumed asymptomatic carrier transmission of COVID-19. JAMA 2020. doi:10.1001/jama.2020.2565.

26. Pan X, Chen D, Xia Y, Wu X, Li T, Ou X, et al. Asymptomatic cases in a family cluster with SARS-CoV-2 infection. The Lancet Infectious diseases 2020. Available from: https://doi.org/10.1016/S14733099(20)30114-6. [Last accessed on 2020 Apr 03].

27. Kimball A, Hatfield KM, Arons M, James A, Taylor J, Spicer K, et al. Asymptomatic and Presymptomatic SARS-CoV-2 Infections in Residents of a Long-Term Care Skilled Nursing Facility - King County, Washington, March 2020. MMWR Morbidity and mortality weekly report 2020.

28. Wei WE LZ, Chiew CJ, Yong SE, Toh MP, Lee VJ. Presymptomatic Transmission of SARS-CoV-2 - Singapore, January 23-March 16, 2020. MMWR Morbidity and mortality weekly report 2020.

29. Centers for Disease Control and Prevention [Internet]. Coronavirus disease-19: Recommendation Regarding the Use ofClothFace Coverings, Especially in Areas of Significant Community-Based Transmission. 2020 Available from: https://www.cdc.gov/coronavirus/2019-ncov/ prevent-getting-sick/cloth-face-cover.html\#studies. [Last accessed on 2020 Apr 03].

30. Leung NHL, Chu DKW, Shiu EYC, Chan K, McDevitt JJ, Hau BJP et al. Respiratory virus shedding in exhaled breath and efficacy of face mask. Nat Med 2020. https://doi.org/10.1038/s41591-020-0843-2. [Last accessed on 2020 Apr 03].

31. World Health Organization [Internet]. Advice on the use of masks in the context of COVID-19. Available from: WHO-2019-nCov-IPC_Masks2020.3-eng.pdf. [Last accessed on 2020 Apr 03]. 